\title{
ACCEPTANCE OF THE ELECTRONIC METHOD OF FILING TAX RETURNS BY SOUTH AFRICAN TAXPAYERS: AN EXPLORATORY STUDY
}

\author{
Raphael W Jankeeparsad* \\ University of Pretoria \\ jankeeparsadr@unizulu.ac.za \\ Thanesha R Jankeeparsad\# \\ University of Pretoria \\ reddyt@unizulu.ac.za \\ Received: March 2015
}

\begin{abstract}
The South African government has benefited to date from information technology in many ways. The importance of understanding and influencing South African citizens' acceptance of $\varepsilon$-Government services is critical, given the substantial investment in government communication, information system technology and the potential for cost saving. One of the most successful $\varepsilon$-Government initiatives, the electronic filing system (eFiling), allows tax returns to be filed electronically. Despite many taxpayers adopting this method, a large number are still using the traditional manual method of filing tax returns. This study utilised the decomposed theory of planned behaviour with factors adjusted specifically for South Africa as a developing country to identify the possible determinants of user acceptance of the efiling system among taxpayers. This exploratory study was conducted by means of a questionnaire survey. For taxpayers using the manual method, lack of facilitating conditions such as access to computer and internet resources was the most significant barrier to eFiling usage, while taxpayers using the electronic method reported perceived usefulness as the primary determinant in their decision to use efiling. Understanding these acceptance factors can extend our knowledge of taxpayers' decision-making and lead to better planning and implementation of future $\varepsilon$-Government initiatives in South Africa and other developing countries.
\end{abstract}

Keywords

$\varepsilon$-Government, eFiling, Tax returns, Electronic filing system, South African Revenue Services

*Mr RW Jankeeparsad is a senior lecturer in the Faculty of Commerce, Administration and Law, University of Zululand, South Africa.

\#Ms TR Jankeeparsad is a senior lecturer in the Faculty of Commerce, Administration and Law, University of Zululand, South Africa.

+Dr G Nienaber is an associate professor in the Department of Taxation, University of Pretoria, South Africa. 


\section{INTRODUCTION}

User acceptance of electronic transactions has improved significantly over the past decade, with more individuals using the internet as a medium of transaction. The results of an annual survey conducted by Mastercard report that the number of active internet users in South Africa who engage in internet transactions has increased to $58 \%$ in 2012 from 44\% in 2009 (Daniels, 2012:1).

Governments across the world have recognised the need to introduce an $\varepsilon$-Government and migrate from traditional manual transactions to electronic transactions using the internet to provide services to its citizens. $\varepsilon$-Government is defined as the process whereby government delivers information to citizens, business and public administration electronically (Lee, Irani, Osman, Balci, Ozkan, \& Medeni, 2008:300). Since 2000, the South African government has taken steps to implement $\varepsilon$-Government across many spheres of government and has invested substantial amounts of money in implementing $\varepsilon$-Government initiatives.

One of the most successful $\varepsilon$-Government initiatives has been electronic filing (eFiling), which was introduced by the South African Revenue Services (SARS) in 2001. The official SARS efiling website describes efiling as a free, online process for the submission of tax returns and declarations and other related services. This free service allows taxpayers, tax practitioners and businesses to register free of charge and submit returns and declarations, make payments and perform a number of other interactions with SARS in a secure online environment (SARS eFiling, 2013). Initially, efiling was used only for the submission and payment of Value Added Tax and Pay As You Earn. The efiling option was expanded in the 2006 filing season to individuals who earned a basic salary and allowances. During the 2007 filing season, efiling was made available to all individual taxpayers and this method allowed individuals to submit their tax returns without supplying supporting documents.

Over the past five years, SARS have made major improvements to the system in order to make the efiling experience more user friendly. Some of the initiatives undertaken by SARS include workshops to assist users in using the efiling system, online videos detailing how to submit tax returns using efiling, the introduction of a live online help facility and the release of an efiling mobisite application which allows users to submit tax returns using their cellular telephones (South African Government News Agency, 2012).

Despite the technological advancement of the system and the initiatives undertaken to present efiling as a more convenient and easier method to use during tax filing season, many South Africans have still not opted to use efiling to submit returns. For the 2012 year of assessment, 4.9 million tax returns were assessed by SARS. Of these, 32071 returns were submitted manually and 1.5 million taxpayers completed their returns at SARS branches (SARS, 2012:39). If SARS is to achieve its goal of paperless transactions and realise a return on its investment with the efiling system, there is a need to understand the acceptance decision of taxpayers with regard to the eFiling system and identify the factors that can affect their decision to use or not use this system.

Studies have been conducted in developed countries (e.g. Ramoo, 2006; Fu, Farn \& Chao, 2006; Hung, Chang \& Yu, 2006; Carter, Schaupp, Hobbs \& Campbell, 2011), but no such study has been conducted in South Africa. These studies contain factors that are applicable to their specific countries; however, there are many unique determinants specific to South Africa as a developing country that need to be investigated. The research problem that this study therefore aims to address is the identification of the determinants of user acceptance of eFiling in South Africa. 


\section{OBJECTIVES, CONTRIBUTIONS AND LIMITATIONS}

The objective of this study is to identify the determinants of user acceptance of the efiling system among taxpayers in South Africa. This was done through the development of a theoretical framework by reviewing literature on the determinants of user acceptance of the efiling system from other countries. In addition, the theoretical framework is supported by empirical evidence obtained through a survey based questionnaire completed by a sample of users of the efiling system and a sample of manual tax filers.

This study contributes to an understanding of taxpayers' acceptance of efiling in South Africa, which is an area that has not received much research attention in the past. From a practical point of view, the results from this study can be used by SARS to either improve the current system or to find ways to attract new users to utilise efiling, which will lead to monetary and temporal cost savings for both the taxpayer and SARS. By understanding adoption factors, SARS can extend and enhance its knowledge of South African taxpayers' decision-making, which could in turn lead to improved strategic planning.

The research identified specific demographics or groups of people with lower efiling usage. Based on this, different advertising strategies could be targeted to this specific group of people which could increase the number of efiling users. In addition to the above, the findings from this study may assist other governmental policy-makers, governmental agencies, and system designers in improving future $\varepsilon$-Government projects in South Africa.

The following limitations are applicable to this study. Firstly, this study is exploratory in nature and the findings cannot be generalised to other countries around the world, as the scope of the study is confined to the cities of Durban and Pretoria in South Africa. Secondly, the findings in this study depend on the honesty of the respondents. Survey research is susceptible to participant bias, and it is known that individuals would agree more on socially desirable answers and disagree more towards socially undesirable answers rather than fully and truly express their feelings and opinions (Ramoo, 2006:62). Lastly, as survey research was used to collect the data, the views of the participants will be those at the specific point in time of conducting the survey. The views of the greater taxpayer population may well differ when measured over a longer time period (Leedy \& Ormrod, 2010:187).

\section{THEORETICAL FRAMEWORK}

The concept of submitting tax returns electronically dates back to 1986, when the United States of America (USA) first introduced a system that processed 25000 refund-only tax returns (Carter, Schaupp \& McBride 2011b:3). Over the years, other countries such as Taiwan, Sweden, Malaysia and Australia have developed advanced systems enabling taxpayers to submit and process their tax returns electronically.

During its inception phase, despite various governments' investment in these systems, most taxpayers were unwilling to give up their paper forms, resulting in an under-utilisation of these systems. In 2008, more than 20 years after the initial introduction of electronic tax filing in the USA, only $60 \%$ of taxpayers made use of the electronic system (Carter et al., 2011b:3). Like all the other countries that introduced an electronic tax system, many South African taxpayers continue to file their tax returns using the conventional manual method. However, through various 
initiatives undertaken by SARS the number of taxpayers that use the system also continues to grow.

However, despite the continuous improvements to the system, SARS has failed to achieve its goal of $100 \%$ paperless returns. Previous research into efiling adoption suggests that technology acceptance and its various models provide an understanding of the factors that promote and hinder the use of an electronic tax system. This study posits that by understanding these factors, researchers, SARS and government policy-makers can gain a better understanding of a taxpayer's decision to use the efiling system or continue with the conventional manual tax return.

\subsection{Technology acceptance}

Technology acceptance refers to an individual's psychological state with regard to his or her voluntary, intended use of a specific technology (Fu, Farn \& Chao, 2006:111). An important consideration in the literature has been the effect of intention-based models which use behavioural intention (BI) to predict actual usage (Chau \& Hu, 2001:701). These models aim to identify factors that influence an individual's behavioural intention to adopt and use a specific technology. Prior empirical research suggests that an individual's intention to use a specific system is positively correlated with the actual use of the system. Therefore, for the research design adopted in this study, intentions are more appropriate since they are measured contemporaneously with beliefs. Furthermore, intention to use is important in the efiling context, where taxpayers' use is voluntary and essential to desired outcomes (Carter et al., 2011b:4).

Research into technology acceptance has resulted in several theoretical models with roots in information systems, psychology and sociology (Venkatesh, Morris, Davis \& Davis, 2003:425). One of the earliest models, The Technology Acceptance Model (TAM) developed by Davis (1989), was developed to explain the determinants of computer acceptance in general and to explain user behaviour across a range of computing technologies and populations. TAM postulates that information system usage is determined by behavioural intention, while behavioural intention is viewed as being jointly determined by the perceived ease of use (PEOU) and perceived usefulness (PU) of the system. TAM was focused on basic information technology usage such as personal computers and email usage. As such TAM has limitations in being applied beyond the workplace because its fundamental constructs of perceived usefulness and perceived ease of use do not fully reflect the variety of user task environment and constraints (Fu et al., 2006:111).

The theory of planned behaviour (TPB), proposed by Ajzen (1985), has been successfully used in predicting intention and usage. According to TPB, an individual's actions are determined by their intentions and perceptions of control, while their intentions are influenced by attitudes towards behaviour, subjective norms, and perceptions of behavioural control (Hung et al., 2006:100). Therefore in the eFiling context, TPB suggests that a taxpayer is more willing to file electronically if he or she has a positive attitude towards using efiling, wants to comply with other important people's opinions on the use of efiling, has access to the required resources to do so and the necessary skills to use the system.

In developing a model for efiling adoption in South Africa, the constructs of both TAM and TPB were used, as neither of the two used independently has been found to provide consistently superior explanations or predictions of behaviour (Fu et al., 2006:112). The decomposed theory of planned behaviour (DTPB), which was proposed by Mathieson (1991) and tested initially by Taylor and Todd (1995), decomposes "attitude" using the PU and PEOU constructs from TAM. The 
research model used in this study is the DTPB in FIGURE 1 and includes a new construct in the form of "trust". In addition to this, "compatibility" will be used as an antecedent of PEOU and PU.

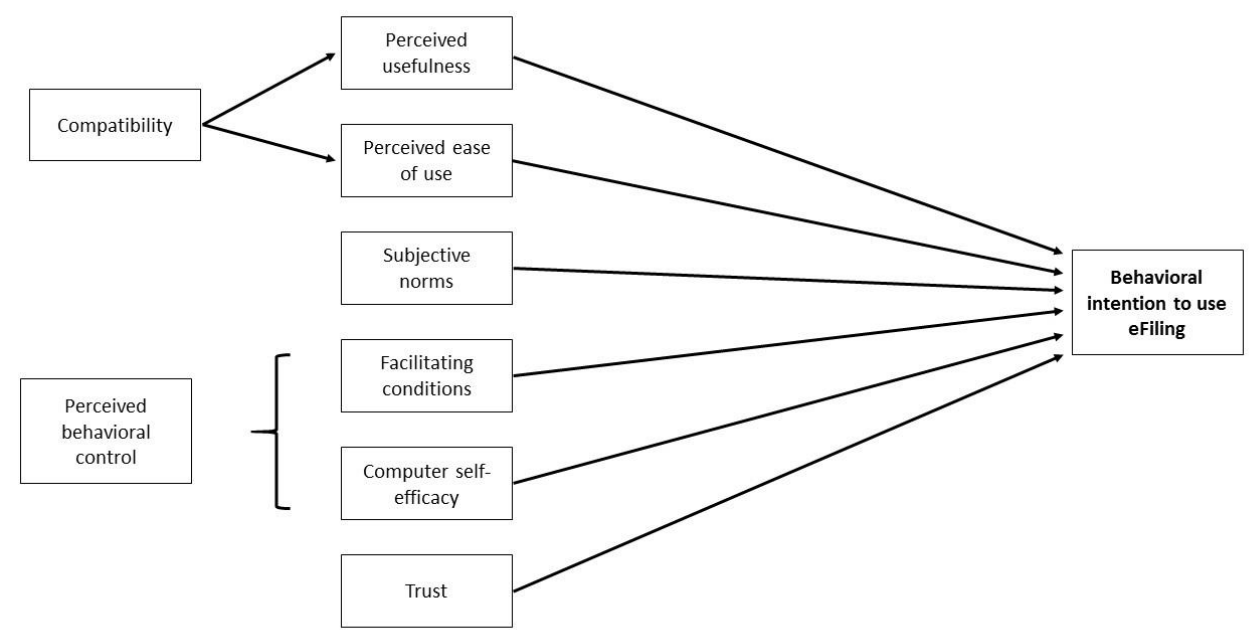

FIGURE 1: Research model

Source: Authors'analysis

\section{DEVELOPMENT OF THE HYPOTHESES}

The constructs presented in FIGURE 1 underpin the development of the hypotheses, which are presented in this section.

\subsection{Perceived usefulness (PU)}

This refers to the degree to which a person believes that using a particular information system would enhance his or her performance (Davis, 1989:320). Chau and Hu (2001:712) concluded empirically in their research that perceived usefulness is the most significant factor for adoption of technology. This relationship has been validated further in the efiling context by Wang (2002) in which it was determined that PU has a direct effect on BI. The ultimate reason that taxpayers will exploit the efiling system is that they find the systems useful to their tax return preparation and submission and will result in significantly less effort and time expended in completing the tax return task.

$H_{1}$ : Perceived usefulness will have a positive effect on behavioural intention to use the efiling system

\subsection{Perceived ease of use (PEOU)}

PEOU refers to the degree to which an individual believes that using a particular information system will be free of effort (Davis, 1989:320). Agarwal and Prasad (1999:381) report that PEOU 
and PU exhibit roughly equivalent influence on BI. Wang (2002:344) observed that PEOU has a stronger influence on BI than PU. Therefore in order for the eFiling system to be used more widely, users must perceive the system to be easy to use and navigate through with as little software knowledge as possible.

$H_{2}$ : Perceived ease of use will have a positive effect on behavioural intention to use the efiling system.

\subsection{Compatibility (COM)}

Compatibility refers to the degree to which the technology fits the potential adopter's previous experience, work practice and needs (Fu et al., 2006:113). Considerable research has indicated that compatibility has a significant effect on technology adoption. Chau and $\mathrm{Hu}$ (2001) examined the effect of compatibility on PU and PEOU in technology acceptance among physicians and found that its effect is greater on PU than PEOU. Fu et al. (2006:119) concluded that compatibility is a significant determinant of both PU and PEOU in the acceptance of efiling in Taiwan.

The practice of tax filing for many individuals in South Africa involves the completion of a manual return. Over time, the taxpayer becomes accustomed to this method of filing returns and is unlikely to adopt new technology that is incompatible with his or her work practices and past experiences. This is more prevalent for taxpayers who do not use information systems in their dayto-day activities. Conversely, those taxpayers who use information systems in their day-to-day activities will find the eFiling system more compatible.

$H_{3}$ : Compatibility will have a positive effect on behavioural intention to use the efiling system

\subsection{Subjective Norms (SN)}

This refers to an individual's perception of relevant others' opinions on whether or not he or she should perform a particular behaviour (Chau \& Hu, 2001:702). A potential eFiling adopter will more likely use the service if those important to him (e.g. supervisors, mentors, friends, family etc.) have adopted and use the eFiling system (Carter et al., 2011b:5). Wang (2010:1) found that most people prepare their tax returns the way their parents did. Hung et al. (2006:113) determined that with electronic filing, SN significantly affects non-users' intention to use. Therefore, this research tests the following hypothesis:

$H_{4}$ : Subjective Norms will have a positive effect on behavioural intention to use the efiling system.

\subsection{Facilitating conditions (FC)}

Facilitating conditions such as access to resources and technology are particularly important for South Africa as a developing country. Fu et al. (2006:121) determined that the absence of facilitating conditions constrained manual taxpayers' behaviour, while Hung et al. (2006:112) found that facilitating conditions are a significant determinant of $B I$ for electronic filing users. The challenges faced by South Africans in terms of access to computer equipment, software and internet connectivity necessary to use efiling can be a barrier to usage and intention to use. If more taxpayers in South Africa have access to computer equipment, internet connectivity, training and have the necessary access to support services regarding efiling, there will be a positive effect on $\mathrm{BI}$ to use and actual usage. 

system.

\subsection{Computer Self-efficacy (CSE)}

This refers to the judgment as to one's ability to use a computer and information system (Wang, 2002:338). Regarding the decision to use efiling, taxpayers who consider computers too complex and believe that they will never be able to control these computers or use the necessary software and interface will prefer to avoid them and are less likely to use them. Fu et al. (2006:121) determined that self-efficacy was higher for electronic filers than manual filers and concluded that individuals with higher self-efficacy in information systems have more options available and therefore feel free to choose whatever they want. Carter, Schaupp, Hobbs and Campbell (2011a:312) observed that self-efficacy has a significant influence on taxpayers' intention to use an electronic system to file tax returns.

$H_{6}$ : Computer self-efficacy will have a positive effect on behavioural intention to use the efiling system.

\subsection{Trust}

The final construct of the model, "trust", includes both trust in the government and trust in the internet. Trust in the government agency providing the electronic service (in South Africa being SARS) hinges upon the belief that it is capable of providing electronic tax services effectively and confidentially (Carter et al., 2011b:6). Taxpayers must believe that the government has deployed the necessary resources and possesses the knowledge, skills and ability to deliver reliable and secure internet-based services. Trust in the internet refers to an individual's perception about transmitting sensitive information over the internet as well as conducting transactions using the internet. The use of the internet to submit a tax return requires a taxpayer to submit very personal and sensitive information via the internet. There is the potential that this information could be intercepted and manipulated (Carter et al., 201la:308).

$H_{7}$ : Trust will have a positive effect on behavioural intention to use the efiling system.

The next section sets out the research design used to test these hypotheses.

\section{RESEARCH DESIGN}

This is an exploratory empirical study in which new data was collected relating to the problem statement and research objectives through survey research. A study of this nature involves the willingness of taxpayers to voluntarily assist the researchers by providing responses to questions that test the hypotheses developed. Due to many factors affecting a taxpayer's willingness to assist such as time constraints, attitude and interest in the problem being researched, a quantitative survey based research strategy was used to obtain data.

\subsection{Sampling}

The target population consisted of taxpayers located in Durban and Pretoria during the period 1 August 2013 to 10 ctober 2013. This period was specifically chosen as it was tax filing season. The researchers made enquiries of visitors to the SARS branches as to what filing method they utilised 
to submit their tax returns. The aim was to identify taxpayers who use the manual method to file tax returns as well as those who use the efiling method. Once this was identified, taxpayers were notified about the purpose of this study and were given the opportunity to participate by completing a questionnaire.

The units of analysis in this study consist of taxpayers who are natural persons. A purposive, snowball sampling technique was used. A list of taxpayers who utilise the manual or electronic method of filing tax returns could not be obtained from SARS and hence there was no other way of determining what method a taxpayer uses. This sampling method therefore is considered to be the most logical and feasible manner by which to identify the target population and units of analysis for this study.

A sample of 50 taxpayers who file manually and 50 who file electronically completed the survey, with 82 of the taxpayers being from Durban and 18 from Pretoria.

\subsection{Data collection, design of questionnaires and data analysis}

Data for this study was collected through two structured questionnaires, one for manual filers and the other for taxpayers who file electronically. The questionnaire, together with an informed consent form, was physically distributed to taxpayers who were willing to participate in the study. The informed consent form detailed the purpose of the study and assured participants that the survey was anonymous and their names would not appear on any document. The participants then completed the questionnaires by choosing the most appropriate option to convey their feelings and opinions.

Regarding the construction of the questionnaires, the questions used to observe and test the constructs of each investigated variable were designed from relevant previous studies on the acceptance of efiling and technology. These questions were then adapted and reconstructed to suit the objectives of this study. The first part of the questionnaire (Section one - questions one to seven) deals with establishing the demographic and educational profile of the target group and consists of questions regarding computer and internet use. Section two of the questionnaire (questions eight onward) tests each construct from the research model. All items in Section 2 were measured using a five-point Likert-type scale with $1=$ "strongly disagree" and 5 = "strongly agree".

In order to establish whether or not participants would experience any problems in interpreting and completing the questionnaire, a pilot study was conducted by pre-testing the questionnaire with two taxpayers, one who used the efiling system and one who did not.

The data collected was analysed using statistical methods. Numerical codes were assigned to each question. Once all questionnaires had been completed these numerical codes were entered onto the coding boxes of each questionnaire. The coded responses were analysed by means of the Statistical Analysis Software (SAS) package. Constructs that have the most influence on a taxpayer's intention to use efiling were then determined.

\section{RESEARCH FINDINGS AND INTERPRETATION}

This section presents the findings from the survey-based questionnaires completed by 100 respondents ( 50 current users of the eFiling system and 50 manual filers). 
TABLE 1 illustrates the results of section one of the questionnaire. This reveals that there was no bias toward a specific gender and, therefore, it can be concluded that the decision to use efiling or not is not dependent on a specific gender, as there was no significant difference in gender distribution between the two groups. An important finding from the analysis revealed that the taxpayers in the sample who use efiling were considerably younger than those who do not use efiling. Furthermore, the educational profile of manual tax filers was lower than those who use efiling. Therefore, there appears to be a correlation between the age and education profile in the two groups, with the majority of the electronic tax filers being younger and having a higher education profile.

The study also revealed that $34 \%$ of manual tax filers do not consider themselves to be computer literate, while, in stark comparison, all respondents who use efiling consider themselves to be computer literate.

Of the manual filers sampled, $34 \%$ have no access to computer or internet facilities at home, while $100 \%$ of the electronic filers have access to computer and/or internet facilities at home. With regard to access to a computer or internet at work, $46 \%$ of the manual filers sampled have no access to either of these, while $34 \%$ have access to a computer only. All respondents from the electronic filers group had access to either a computer and/or the internet and reported that they access the internet once a week or more, while $40 \%$ of manual filers report that they never access the internet at all. Based on these findings it is clear that those taxpayers to whom these computer and internet facilities are readily available, either at home or at work, use the internet more often and also use the efiling method of submitting tax returns.

\subsection{Analysis of constructs and hypotheses}

The first test carried out on the data was the reliability test on the multiple item construct. The Cronbach's alpha value was used to test the reliability of the items for the various constructs. It is a reliability measure coefficient that reflects how well items in a set are positively correlated to one another. Cronbach alpha values greater than .70 indicate inter item consistency. Thereafter, the $T$-test was used to compare the results of each construct between the two groups. Probability values $(p)$ of $<.0001$ suggest that both groups differ significantly on a specific construct. The results from the $T$-test returned probability values of $<.0001$ for all constructs tested, suggesting that the two groups differ significantly in their opinions regarding these constructs.

The results of both the questionnaires support and confirmed each of the seven hypotheses tested, as indicated in TABLE 4.

The results of the analysis revealed that current users of efiling have a strong intention to continue using this system to submit their tax returns. A mean of 4.56 was returned for behavioural intention ( $B I)$, as illustrated in $T A B L E 3$, indicating that current users of the system are happy with their choice of tax filing method, as it is beneficial and useful in filing their returns.

In contrast to this, taxpayers who do not use efiling have a strong intention to continue using their current manual method of filing returns. A mean of 1.98 was returned, as illustrated in TABLE 2, suggesting that non-users of the efiling system have no intention of adopting eFiling for their future tax returns. 
TABLE 1: Sample demographics, education profile and access to resources

\begin{tabular}{|c|c|c|c|c|}
\hline & \multicolumn{2}{|c|}{ Users of eFiling } & \multicolumn{2}{|c|}{ Manual tax filers } \\
\hline & Count & Percentage & Count & Percentage \\
\hline \multicolumn{5}{|l|}{ Age } \\
\hline $20-30$ years & 21 & $42 \%$ & 1 & $2 \%$ \\
\hline $31-40$ years & 20 & $40 \%$ & 10 & $20 \%$ \\
\hline $41-50$ years & 5 & $10 \%$ & 15 & $30 \%$ \\
\hline $51-60$ years & 4 & $8 \%$ & 23 & $46 \%$ \\
\hline Above 60 years & - & - & 1 & $2 \%$ \\
\hline Average age & 34 years & & 48 years & \\
\hline \multicolumn{5}{|l|}{ Gender } \\
\hline Male & 29 & $58 \%$ & 29 & $58 \%$ \\
\hline Female & 21 & $42 \%$ & 21 & $42 \%$ \\
\hline \multicolumn{5}{|l|}{ Highest Education } \\
\hline Secondary & 1 & $2 \%$ & 18 & $36 \%$ \\
\hline Tertiary & 49 & $98 \%$ & 32 & $64 \%$ \\
\hline \multicolumn{5}{|l|}{ Computer Literate } \\
\hline yes & 50 & $100 \%$ & 33 & $66 \%$ \\
\hline No & - & - & 17 & $34 \%$ \\
\hline \multicolumn{5}{|c|}{ Access to computer and internet at home } \\
\hline Computer only & 7 & $14 \%$ & 12 & $24 \%$ \\
\hline Computer and internet & 27 & $54 \%$ & 1 & $2 \%$ \\
\hline Internet only & 16 & $32 \%$ & 20 & $40 \%$ \\
\hline No access & - & - & 17 & $34 \%$ \\
\hline \multicolumn{5}{|c|}{ Access to computer and internet at work } \\
\hline Computer only & 1 & $2 \%$ & 17 & $34 \%$ \\
\hline Computer and internet & 34 & $68 \%$ & 6 & $12 \%$ \\
\hline Internet only & 15 & $30 \%$ & 4 & $8 \%$ \\
\hline No access & - & - & 23 & $46 \%$ \\
\hline \multicolumn{5}{|l|}{ Frequency of internet use } \\
\hline Once a week or more & 50 & $100 \%$ & 14 & $28 \%$ \\
\hline Less than once a month & - & - & 4 & $8 \%$ \\
\hline Once a month & - & - & 12 & $24 \%$ \\
\hline Never & - & - & 20 & $40 \%$ \\
\hline
\end{tabular}

Source: Authors' analysis 


\subsubsection{Manual tax filers}

Of all the constructs tested, facilitating conditions such as access to computer resources and technology had the most material effect on these taxpayers' behavioural intention, as it returned the lowest mean, as illustrated in TABLE 2 and TABLE 4. The challenges faced by these taxpayers in terms of access to computer equipment, software and internet connectivity necessary to use efiling proved to be a barrier to usage and intention to use. These findings are consistent with the study conducted by $\mathrm{Fu}$ et al. (2006:121), who determined that the absence of facilitating conditions constrained manual taxpayers' behaviour and therefore the efiling method may not reach the entire population, and a "digital divide" may exist. In order to overcome this barrier of lack of facilitating conditions, SARS has launched a mobi site to submit tax returns which can be accessed by cellular phones. However, none of the respondents interviewed were aware of this new technology.

As a result of the lack of facilitating conditions and a high percentage of respondents not being computer literate, computer self-efficacy was found to be a determinant of behavioural intention. Parallel with the study by Wang (2002:345), our results show that the lower a taxpayer's computer self-efficacy, the less likely he/she will be pursuing electronic means to file tax returns.

Perceived usefulness and perceived ease of use both have a positive effect on behavioural intention to use efiling, as the respondents in this group did not believe that the system will be useful to them or easy to use. Similar to the study conducted by Wang (2002:345), perceived ease of use had a stronger effect on intention to use than usefulness. This correlates with their computer experience and access to resources, as the lack of use of the internet and computers in general resulted in these taxpayers perceiving the efiling system to be generally difficult to use. The results are also consistent with Carter et al. (201lb:11), as taxpayers who believe an electronic option will help them file their taxes more quickly and efficiently than traditional alternatives are more likely to adopt the efiling system. The taxpayers sampled did not believe that the system could enhance their effectiveness in preparing their returns and neither did they believe it will increase the speed at which their returns will be processed.

The study revealed that compatibility of the efiling system with a taxpayer's occupation and dayto-day activities is a crucial antecedent to their behavioural intention to use the system. Of the respondents in this group, $46 \%$ did not use information systems in their employment, and this correlates with their intention to use manual filing. Consistent with the findings by $\mathrm{Fu}$ et al. (2006:121) and Hung et al. (2006:110), compatibility is an important determinant in a taxpayer's intention to use efiling.

Regarding subjective norms, taxpayers with family, friends and influences who encourage the use of efiling are more likely to use this option. The results for this group revealed that their respective family, friends and influences did not encourage the use of the efiling system, thereby directly influencing their decision to file manually. This finding is consistent with the study by Tan and Foo (2012:68).

Finally, trust of the internet and the efiling system had an impact on their intention to use manual filing. This correlates with how often the users use the internet and whether or not they conclude any other transaction electronically using the internet. The respondents did not believe that the efiling system has put in the necessary safeguards to maintain the integrity of personal information being submitted. 
TABLE 2: Questions and results for manual tax filers

\begin{tabular}{|c|c|c|}
\hline Construct & Question & Mean \\
\hline PU & eFiling is beneficial to me & 1.34 \\
\hline PU & $\begin{array}{l}\text { Using efiling would enhance my effectiveness in preparing my tax return } \\
\text { resulting in fewer errors }\end{array}$ & 2.36 \\
\hline PU & Using eFiling would improve the speed at which my tax return is processed & 2.56 \\
\hline PEOU & Learning how to use the eFiling system will be easy for me & 2.44 \\
\hline PEOU & I will find it easy to submit my tax return using eFiling & 2.46 \\
\hline PEOU & It will be easy for me to become skilful at using the eFiling system & 2.00 \\
\hline COM & Using eFiling suits my occupation & 2.38 \\
\hline COM & Using the efiling system will be compatible with my day-to-day activities & 2.44 \\
\hline COM & Using the eFiling system will fit well into my lifestyle & 2.40 \\
\hline SN & My peers, friends and family think that I should use eFiling & 2.78 \\
\hline SN & People who influence me think that using eFiling is a good idea & 2.84 \\
\hline SN & $\begin{array}{l}\text { I would use eFiling because it is advertised as being more effective and } \\
\text { efficient than manual filing }\end{array}$ & 2.52 \\
\hline $\mathrm{FC}$ & Resources required to use efiling are readily available to me & 2.38 \\
\hline FC & It will be easy for me to get technical support when using the eFiling system & 1.98 \\
\hline $\mathrm{FC}$ & $\begin{array}{l}\text { I would like to use eFiling but have no access to the resources required to do } \\
\text { so }\end{array}$ & 3.30 \\
\hline CSE & I will feel comfortable using the eFiling system on my own & 2.50 \\
\hline CSE & I will be able to teach others how to use the eFiling system & 2.38 \\
\hline CSE & $\begin{array}{l}\text { I will be able to use efiling without any technical support or learning } \\
\text { tutorials }\end{array}$ & 2.34 \\
\hline TRUST & I trust the eFiling system with my personal information & 2.48 \\
\hline TRUST & $\begin{array}{l}\text { I trust the eFiling system but I am afraid of hackers and other internet } \\
\text { threats }\end{array}$ & 2.82 \\
\hline TRUST & I do not trust the internet with any of my personal and financial information & 4.00 \\
\hline TRUST & $\begin{array}{l}\text { I am confident the necessary safeguards have been put into place to protect } \\
\text { my confidential information }\end{array}$ & 2.46 \\
\hline $\mathrm{BI}$ & I intend to use eFiling next year & 1.98 \\
\hline
\end{tabular}

Source: Authors' analysis

\subsection{2 عlectronic tax filers}

Perceived usefulness and compatibility were the strongest determinants of behavioural intention to use efiling, per the results in TABLE 3 and TABLE 4, which is consistent with the results of the 
study by Fu et al. (2006:119). The ultimate reason these taxpayers use the eFiling system is that they find the system useful to their tax return preparation and submission and believe that it results in significantly less effort and time in completing the tax return task. Using the internet more frequently, these taxpayers find using the efiling system more convenient than filing manually and anticipate faster processing times from SARS.

These taxpayers found the efiling system relatively easy to use and also demonstrated a higher computer self-efficacy. This is due to their computer literacy levels being high and their regular internet use. Therefore, consistent with the findings by Hung et al. (2006:111), both perceived ease of use and computer self-efficacy have a positive impact on behavioural intention to use the efiling system.

The role that facilitating conditions have on behavioural intention also proved to be vital for users of the efiling system. Computer and internet resources were readily available to all the respondents in this group, making it easy to make use of the electronic method of filing tax returns.

The family, friends and influences of users of efiling recommend using this method and hence have a positive impact on behavioural intention to use. This is consistent with Wang (2010:1). $70 \%$ of these taxpayers also responded that part of the reason they use efiling is because it is advertised as being more effective and efficient than manual filing. It can be concluded then that adopters of efiling pay more attention to such advertisements than non-adopters.

These respondents concluded that they have the necessary level of trust in the internet and efiling system to warrant the use of efiling. This is in direct correlation with frequency of internet use and use of information systems at work. These users have confidence that SARS has implemented the necessary safeguards and access controls to protect sensitive information being transmitted online.

\section{IMPLICATIONS OF THIS STUDY, FUTURE RESEARCH AND CONCLUSION}

Although the majority of South African taxpayers have bought into the efiling concept, there is a significant percentage that still prefer the manual method of filing tax returns, preventing SARS from achieving its target of paperless tax filing. By understanding the adoption factors, SARS can extend its knowledge of taxpayers' decision-making, which may in turn lead to improved strategies.

- Facilitating conditions and computer self-efficacy were the strongest factors influencing the use of manual filing. To encourage these taxpayers to use efiling, SARS needs to make the necessary avenues available. Steps have been taken by SARS to improve and assist in the efiling process by introducing a mobi site and a Help-you-eFile service that allows a SARS agent to assist a taxpayer in real time when completing his/her tax return. However, none of the respondents in this study were aware of these two available features. SARS therefore has to improve its advertising strategy so that more taxpayers are aware of these new developments and will be willing to try the efiling method.

- Subjective norms are another major motivating factor which encourages taxpayers to use efiling. In order to achieve its target of full adoption, SARS should contribute to raising the ability of uninformed and inexperienced users to use efiling by educating the public with the support of their employers. 
TABLE 3: Questions and results for electronic tax filers

\begin{tabular}{|c|c|c|}
\hline Construct & Question & Mean \\
\hline PU & efiling is beneficial to me & 4.72 \\
\hline PU & $\begin{array}{l}\text { Using efiling enhances my effectiveness in preparing my tax return resulting } \\
\text { in fewer errors }\end{array}$ & 4.28 \\
\hline PU & Using efiling enhances the speed at which my tax return is processed & 4.62 \\
\hline PEOU & Learning how to use the eFiling system was easy for me & 4.32 \\
\hline PEOU & I find it easy to submit my tax return using efiling & 4.38 \\
\hline PEOU & It was easy for me to become skilful at using the efiling system & 4.18 \\
\hline COM & Using efiling suits my occupation & 4.54 \\
\hline $\mathrm{COM}$ & Using the efiling system is compatible with my day-to-day activities & 4.56 \\
\hline COM & Using the eFiling system fits well into my lifestyle & 4.40 \\
\hline SN & My peers, friends and family encourage me to use efiling & 3.56 \\
\hline SN & People who influence me think that using eFiling is a good idea & 3.94 \\
\hline SN & $\begin{array}{l}\text { I use efiling because it is advertised as being more effective and efficient } \\
\text { than manual filing }\end{array}$ & 3.50 \\
\hline $\mathrm{FC}$ & Resources required to use efiling are readily available to me & 4.58 \\
\hline $\mathrm{FC}$ & It is easy for me to get technical support when using the efiling system & 3.18 \\
\hline CSE & I feel comfortable using the efiling system on my own & 4.54 \\
\hline CSE & I am able to teach others how to use the efiling system & 3.94 \\
\hline CSE & $\begin{array}{l}\text { I am able to use the efiling system without any technical support or learning } \\
\text { tutorials }\end{array}$ & 4.14 \\
\hline TRUST & I trust the efiling system with my personal information & 4.36 \\
\hline TRUST & I trust the efiling system but I am afraid of hackers and other internet threats & 3.56 \\
\hline TRUST & I do not trust the internet with any of my personal and financial information & 2.66 \\
\hline TRUST & $\begin{array}{l}\text { I am confident the necessary safeguards have been put into place to protect } \\
\text { my confidential information }\end{array}$ & 3.98 \\
\hline $\mathrm{BI}$ & I intend to continue using eFiling next year & 4.56 \\
\hline
\end{tabular}

Source: Authors' analysis

- In order to retain current users of the system, SARS must make it easier to get technical support by employing more customer agents during filing season as the lowest response from users of the efiling system related to obtaining technical support from SARS agents regarding the system. 


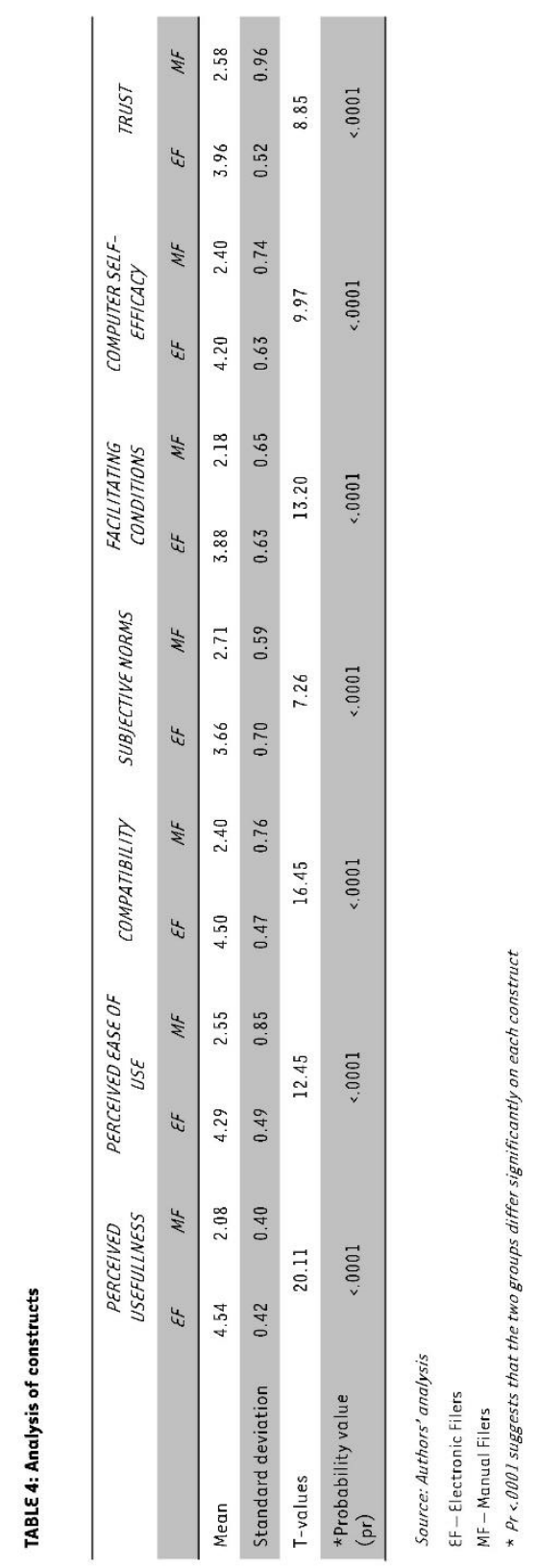


- For the South African governmental policy-makers responsible for future strategic planning and implementation of $\varepsilon$-Government services, this study suggests that the constructs investigated should be monitored to evaluate the performance of $\varepsilon$-Government services. In addition to this, security mechanisms, technical assistance and ease of use of these $\varepsilon$ Government services must be continuously appraised and improved.

Continued research is needed to address this study's limitations. Some avenues that can be pursued include:

- Carrying out a similar study in other areas of South Africa to determine if the results are consistent with this study;

- Investigating the challenges faced by current users of the efiling system and ways that the system can be improved;

- Investigating the obstacles faced by older taxpayers in obtaining technical assistance from SARS call centre agents regarding efiling;

- Conducting further research to determine whether this study can be replicated in other $\varepsilon$ Government services in South Africa.

This exploratory study set out to determine the possible determinants of user acceptance of the efiling system among taxpayers in South Africa. All of the seven constructs investigated proved to have a material effect on behavioural intention to use the efiling system. The study also has the merits of conducting a technology acceptance investigation in a real-world tax-filing setting involving individual taxpayers and the two tax-filing methods. Such a setting should increase the relevance and reliability of the results. For manual tax filers, facilitating conditions such as access to computer resources and technology had the most material effect on their behavioural intention to continue using the conventional manual method. South Africa being a developing country, access to such resources are not readily available to the majority of the population and this proved to be a material barrier to efiling usage. For the users of the efiling system, perceived usefulness and compatibility were the strongest determinants of behavioural intention to use efiling. Continued research into efiling is needed to improve this study and to address its limitations. Nonetheless, it is hoped that this study provides insight into and understanding of taxpayers' acceptance of eFiling in South Africa.

\section{LIST OF REFERENCES}

Agarwal, R. \& Prasad, J. (1999). Are individual differences germane to the acceptance of new information technologies? Decision Sciences, 30(2), pp. 361-391.

Ajzen, I. (1991). The theory of planned behaviour. Organisational behaviour and human decision processes, 50(1), pp. 179-211.

Carter, L., Schaupp, L.C., Hobbs, J. \& Campbell, R. (2011a). The role of security and trust in the adoption of online tax filing. Transforming Government: People, Process, Policy, 5(4), pp. 303-318.

Carter, L., Schaupp, L.C. \& McBride, M.E. (2011b). The U.S. e-file initiative: an investigation of the antecedents to adoption from the individual taxpayers' perspective. $E$-Service Journal, 7(3), pp. 219 .

Chau, P.Y.K. \& Hu, P.J.W. (2001). Information technology acceptance by individual professionals: a model comparison approach. Decision Sciences, 32(4), pp. 699-719. 
Daniels, H. (2012). MasterCard survey: online shopping increases in South Africa. Available: http://www.techsmart.co.za/features/news/MasterCard_Survey:_Online_shopping_increases_in_So uth_Africa.html. (Accessed 4 February 2013)

Davis, F.D. (1989). Perceived usefulness, perceived ease of use and user acceptance of information technology. MIS Quarterly, 13(3), pp. 319-340.

Fu, J.R., Farn, C.K. \& Chao W.P. (2006). Acceptance of electronic tax filing: a study of taxpayer intentions. Information \& Management, 43, pp. 109-126.

Hung, S.Y., Chang, C.M. \& Yu, T.J. (2006). Determinants of user acceptance of the e-government services: the case of online tax filing and payment system. Government Information Quarterly, 23(1), pp. $97-122$.

Lee, H., Irani, Z., Osman, I.H., Balci, A., Ozkan, S. \& Medeni, T.D. (2008). Research note: toward a reference process model for citizen-oriented evaluation of e-government services. Transforming Government: People, Process, Policy, 2(4), pp. 297-310.

Leedy, P.D. \& Ormrod, J.E. (2010). Practical Research Planning and Design, $9^{\text {th }}$ edition. Upper Saddle River, New Jersey: Pearson Education.

Mathieson, K. (1991). Predicting user intentions: comparing the technology acceptance model with the theory of planned behaviour. Information Systems Research, 2(3), pp. 173-191.

Ramoo, V. (2006). Determinants of perceived ease of use of e-filing. Unpublished master's dissertation. Malaysia: Universiti Sains Malaysia.

SARS eFiling. (2013). What is eFiling? Available: http://www.sarseFiling.co.za/AboutPage.aspx. (Accessed 3 March 2013).

South African Government News Agency (SARS). (2012). Taxpayers can use cellphones to file returns. Available: http://oldsanews.gcis.gov.za/news/12/12092808551001. (Accessed 10 December 2012).

South African Revenue Services. (2012). Annual Report 2011-2012. Available: http://www.sars.gov.za/home.asp?pid=4150\&tid=65\&s=pubs\&show=1045. (Accessed 14 December 2012).

Tan, T.H. \& Foo, Y.F. (2012). Predicting taxpayer's intentions of adopting electronic tax-filing ( $\varepsilon-$ Filing) in Malaysia. Journal of Accounting - Business \& Management, 19(2), pp. 59-71.

Taylor, S. \& Todd, P.A. (1995). Understanding information technology usage: a test of competing models. Information Systems Research, 6(1), pp. 144-176.

Venkatesh, V., Morris, M.G., Davis, G.B. \& Davis F.D. (2003). User acceptance of information technology: toward a unified view. MIS Puarterly, 27(3), pp. 425-478.

Wang, J. (2010). Your take: how do you prepare your taxes? Available: http://www.bargaineering.com/articles/your-take-how-do-you-prepare-your-taxes.html. (Accessed 3 October 2013).

Wang, Y.S. (2002). The adoption of electronic tax filing systems: an empirical study. Government Information Quarterly, 20(1), pp. 333-352. 